\title{
AFLP markers support separation of Solanum nodiflorum from Solanum americanum sensu stricto (Solanaceae)
}

\author{
M. L. K. Manoko ${ }^{1}$, R. G. van den Berg ${ }^{2}$, R. M. C. Feron ${ }^{1}$, G. M. van der Weerden ${ }^{3}$, and \\ C. Mariani $^{1}$ \\ ${ }^{1}$ Department of Experimental Botany, Radboud University Nijmegen, Nijmegen, The Netherlands \\ ${ }^{2}$ Biosystematics group, Wageningen University, Wageningen, The Netherlands \\ ${ }^{3}$ Botanical and Experimental Garden, Radboud University Nijmegen, Nijmegen, The Netherlands
}

Received January 24, 2006; accepted February 20, 2007

Published online: August 1, 2007

(C) Springer-Verlag 2007

\begin{abstract}
This study was aimed at examining the relationships between the African material of Solanum americanum (also designated as $S$. nodiflorum), accessions of this taxon from other geographical areas, and American S. americanum using AFLP markers. 96 individuals representing 39 accessions of S. americanum sensu lato and related diploid species from the widest possible geographical range, and one accession of $S$. dulcamara (as outgroup) were used. The AFLP results suggested that American S. americanum differs from $S$. nodiflorum and that the material investigated in this study can be assigned to three different species: $S$. americanum sensu stricto, $S$. nodiflorum and a Solanum species from Brazil. These species can be differentiated based on a combination of floral and fruit characteristics.
\end{abstract}

Key words: Africa, AFLP, nomenclature, Solanum americanum, Solanum nodiflorum.

The importance of Solanum L. section Solanum species in Africa cannot be overestimated. Species in this section constitute one of the largest groups of leafy vegetables, and are an important source of income for "Mnafu" (the
Swahili name for section Solanum species) growers in both rural and urban areas (Edmonds and Chweya 1997, Schippers 2000, Manoko and van der Weerden 2004). Furthermore, in Africa, where about $80 \%$ of people still live in rural areas, section Solanum species are used in traditional medicine, the sole source of primary health care in these areas. The section is one of the largest and most variable species groups of the genus with its greatest diversity in the New World tropics (Edmonds and Chweya 1997). There are diploid, tetraploid, and hexaploid species. The present study concentrates on the diploid species.

Solanum americanum Mill. and S. nodiflorum Jacq., which have shown to have both local and scientific importance, are considered by some authors as two separate species and by others as one species. The two taxa show much resemblance in their general morphology. Philip Miller in 1768 described S. americanum based on a specimen (Miller s.n.) cultivated at Chelsea Physic Garden, originally from Virginia, North America. Nicolaus Jacquin, based on type material from the African island of Mauritius (Jacquin S.n.), described S. nodiflo- 
rum in 1789. The dispute about the identity of the two species emerged after Edmonds (1971) combined them into one species: Solanum americanum. One group of taxonomists agreed with Edmonds reduction (e.g. Gentry and Standley 1974; D’Arcy 1974a, b; Symon 1981, 1985; Howard 1989; D’ Arcy and Rakotozafy 1994; Bosser et al. 2000), while others continued handling them as different species (Henderson 1974, Morton 1976, Heiser et al. 1979, Wiggins 1980). Even when they have been considered conspecific, different authors based on different morphological characteristics recognized different varieties. For example, based on hair characteristics Edmonds (1971) recognized two varieties under $S$. americanum: $S$. americanum var. nodiflorum (Jacq.) Edmonds and $S$. americanum var. americanum whereas D'Arcy (1974b), using pedicel position, distance between internodes and flower characteristics combined Edmonds varieties under $S$. americanum var. americanum, describing a new variety $S$. americanum var. baylisii D'Arcy. In Australia, Henderson, (1974), based on pedicel position at fruiting, presence or absence of stone cells, margins of adult leaves and number of fruits per peduncle recognized two subspecies under $S$. nodiflorum, i.e. S. nodiflorum subsp. nodiflorum and $S$. nodiflorum subsp. nutans $\mathrm{H}$. J. Henderson. These observations indicate that the taxonomic situation of $S$. americanum and $S$. nodiflorum is still unclear and this fact may hamper the utilization of the available knowledge about the two taxa.

Our current study was therefore designed to address the taxonomic question whether or not material of $S$. americanum (also designated as $S$. nodiflorum) from Africa and other geographical areas was synonymous with material of $S$. americanum from America. Solanum chenopodioides and $S$. physalifolium were added to this study because, based on the list provided by Edmonds and Chweya (1997), they are the only other diploid species found in Africa. Furthermore, the former was what D'Arcy (1994b) considered to be $S$. americanum var. baylisii.

We generated AFLP markers from material of $S$. americanum and related diploid species collected from the widest possible geographical range of the target species. According to Becker et al. (1995), AFLPs are arbitrarily spread over the whole genome and co-migrating bands are predominantly homologous in closely related groups (Waugh et al. 1997, Rademaker et al. 2000). AFLP markers have previously been successful is resolving taxonomic problems and elucidating relationships among species in the genus Solanum (Kardolus et al. 1998; Mace et al. 1999a, b; Coulibaly et al. 2002; Jacoby et al. 2003; Dehmer and Hammer 2004; Olet 2004).

\section{Materials and methods}

Plant material. We acquired seeds of Solanum section Solanum accessions and grew them in the greenhouse. One individual per accession was taken to count chromosome numbers in the root tip cells following standard procedures. Results confirmed that accessions used in this study were all diploid. Identification of species followed Edmonds and Chweya (1997). A total of 96 individuals representing 39 accessions of $S$. americanum, related diploid species, and Solanum dulcamara L. (as outgroup) were used in this study. (Table 1). Except for 95160phy and A3455amer, 2 or 3 individuals represented each accession.

Collection of leaf materials and DNA isolation. $40 \mathrm{mg}$ of leaf material from each of the 96 individuals was collected in a $1.5 \mathrm{ml}$ Eppendorf tube and immersed in liquid nitrogen. Isolation of DNA followed the Promega genomic DNA purification kit procedure. After isolation, DNA was dissolved in $100 \mu \mathrm{l}$ DNA hydration liquid and stored at $-20^{\circ} \mathrm{C}$. DNA concentration was measured using a spectrophotometer and the quality was checked by electrophoresis in a $1 \%$ agarose gel. $0.5 \mu \mathrm{g}$ of DNA was used for AFLP analysis.

AFLP analysis. AFLP analysis followed a modified version of the protocol of Vos et al. (1995). EcoRI and MseI restriction enzymes were used for digestion of genomic DNA. Pre-amplification was achieved using $E c o \mathrm{RI}+\mathrm{A}$ and $\mathrm{Mse} \mathrm{I}+\mathrm{C}$ primers and products diluted 50 times in $10 \mathrm{mM}$ Tris (pH8.0). Selective amplification was done using a D4 dye (Beckman Coulter) labeled EcoRI primer and an unlabeled MseI primer. Two primer combinations were used: $E c o \mathrm{RI}+\mathrm{AAC} / M s e \mathrm{I}+$ 
Table 1. Accessions of diploid species and their country of origin

\begin{tabular}{|c|c|c|c|c|}
\hline RU Accession No. & Accession code & Received as: & Identified as & Country of origin \\
\hline 904750026 & 90026amer & S. photeinocarpum & S. americanum & China \\
\hline 944750234 & 94234amer & Nothocestrum latifolium & S. americanum & USA (Hawaii) \\
\hline 954750186 & 95186amer & S. americanum & S. americanum & Brazil \\
\hline 954750354 & 95354amer & S. americanum & S. americanum & Mexico \\
\hline 954750356 & 95356amer & S. americanum & S. americanum & Venezuela \\
\hline 984750118 & 98118amer & S. americanum & S. americanum & Australia \\
\hline 994750056 & 99056amer & S. nigrum & S. americanum & India \\
\hline A04750035 & A0035amer & Solanum sp. & S. americanum & Tanzania \\
\hline A14750028 & A1028amer & S. americanum? & S. americanum & Uganda \\
\hline A14750066 & A1066amer & S. nigrum & S. americanum & Germany? \\
\hline A14750092 & A1092amer & S. nigrum? & S. americanum & Mexico \\
\hline A14750099 & A1099amer & S. americanum & S. americanum & Brazil \\
\hline A14750130 & A1130amer & S. photeinocarpum & S. americanum & China \\
\hline A14750414 & A1414amer & S. retroflexum? & S. americanum & Zimbabwe \\
\hline A14750415 & A1415amer & S. retroflexum? & S. americanum & Zimbabwe \\
\hline A14750424 & A1424amer & S. nigrum & S. americanum & Mauritius \\
\hline A14750425 & A1425amer & S. nigrum & S. americanum & Mauritius \\
\hline A14750426 & A1426amer & S. nigrum & S. americanum & Mauritius \\
\hline A14750427 & A1427amer & S. nigrum & S. americanum & Mauritius \\
\hline A34750450 & A3450amer & S. americanum & S. americanum & USA \\
\hline A 34750451 & A3451amer & S. americanum & S. americanum & Cuba \\
\hline A34750453 & A3453amer & S. americanum & S. americanum & Cuba \\
\hline A34750454 & A3454amer & S. americanum & S. americanum & Cuba \\
\hline A34750455 & A3455amer & S. americanum & S. americanum & Cuba \\
\hline A 34750457 & A3457amer & S. americanum & S. americanum & USA \\
\hline A 34750458 & A3458amer & S. americanum & S. americanum & USA \\
\hline A 34750459 & A3459amer & S. americanum & S. americanum & USA \\
\hline A34750460 & A3460amer & S. americanum & S. americanum & USA \\
\hline A34750461 & A3461amer & S. americanum & S. americanum & USA \\
\hline A34750463 & A3463amer & S. americanum & S. americanum & USA \\
\hline A34750464 & A3464amer & S. americanum & S. americanum & USA \\
\hline 884750042 & 88042chen & S. chenopodioides & S. chenopodioides & Switzerland \\
\hline 904750124 & 90124chen & S. chenopodioides & S. chenopodioides & Australia \\
\hline 914750076 & 91076chen & S. chenopodioides & S. chenopodioides & France? \\
\hline 944750185 & 94185 chen & S. sinaicum subsp. sublobatum & S. chenopodioides & Romania? \\
\hline 954750185 & 95185chen & S. ottonis $/ S$. gracilius & S. chenopodioides & Australia \\
\hline 964750073 & 96073phy & S. sarrachoides & S. physalifolium & Canada \\
\hline 954750160 & 95160phy & S. nitidibaccatum & S. physalifolium & France? \\
\hline 954750170 & 95170phy & S. sarrachoides & S. physalifolium & UK? \\
\hline 904750062 & 90062dulca & S. depilatum & S. dulcamara & Poland \\
\hline
\end{tabular}

Column 1: accession number of Radboud University Botanical and Experimental Garden seed collection; column 2: code used in this study, which was derived from the accession number and the first few letters of the specific name (column 4); column 3: name provided by the seed donor; column 4: name given after identification of the material; column 5: country of origin 
$\mathrm{CAC}$ and $E c o \mathrm{RI}+\mathrm{ACC} / M s e \mathrm{I}+\mathrm{CAT}$. Selective amplification products were diluted 10 times in Sample Loading Solution (SLS, Beckman Coulter). Two microliters of this dilution were added to $33 \mu 1$ of SLS buffer containing $0.2 \mu \mathrm{l}$ of CEQ DNA size standard 600 (Beckman Coulter). Resulting fragments were analysed using Beckman Coulter $8000^{\mathrm{TM}}$ fragment analysis system with default values of study parameter with exception of size standard and model of study. In this study size standard 600 and cubic model were used.

Data analysis. The AFLP data from each primer combination separately and combined, were analysed using both phenetic and cladistic approaches, and NJ and MP trees were generated. During MP analysis, for each data set, two heuristic searches were performed and trees from the first heuristic search were used as starting trees in the second search. Afterwards, the tree topology from all methods was compared. Jackknife analyses $(10,000$ replicates) were run with both $\mathrm{NJ}$ and MP settings. All analyses were performed using PAUP version 4.0 b10 (Swofford 2001).

Morphological comparison. On the basis of our AFLP results, we compared the three clusters of $S$. americanum accessions for a number of morphological characteristics that Knapp (2001) considered important in identifying monophyletic groups and distinguishing species in the genus Solanum. To this end, we examined inflorescence, flower, and fruit characteristics of most of the accessions that were also used for AFLP analysis (Table 2).

\section{Results}

AFLP fragments. The $E c o \mathrm{RI}+\mathrm{AAC} / \mathrm{Mse} \mathrm{I}+$ CAC primer combination produced 248 bands in total, of which $224(90.3 \%)$ were polymorphic. The $E c o \mathrm{RI}+\mathrm{ACC} / M s e \mathrm{I}+\mathrm{CAT}$ primer combination produced 225 bands, all being polymorphic. On average, the EcoRI $+\mathrm{ACC} /$ $M s e I+C A T$ primer combination produced 40-50 bands per individual whereas Eco$\mathrm{RI}+\mathrm{AAC} / \mathrm{Mse}+\mathrm{CAC}$ produced $30-40$ bands per individual.

Clustering pattern and species recognition. Figure 1 shows the NJ tree based on all fragments generated by the two primer combinations. Five clearly distinct and well supported clusters were obtained that could be separated into two groups, A and B. Group A contained three relatively closely related clusters (I-III), all made up of individuals that were received under many different names and identified by us as $S$. americanum sensu lato. These were clearly separated from group B that consisted of two clusters (IV and V) of $S$. chenopodioides Lam. and $S$. physalifolium Rusby accessions, respectively, which were also previously identified as such. The three clusters I, II and III of $S$. americanum were separated from each other by substantial genetic distances comparable to that between $S$. physalifolium and $S$. chenopodioides. This suggested that individuals of group A were not all $S$. americanum as they were received or identified based on morphology.

Cluster I (NJ Jackknife support 100\% in Fig. 1) is composed of accessions from different geographical areas, i.e. Africa, Australia, India, China Venezuela, Mexico, Cuba and Hawaii, but the AFLP-based subclusters that can be distinguished within cluster I do not reflect these geographical origins. There is also no clustering of accessions according to pedicel orientation (erect or deflexed), one of the characters used by Henderson (1974) to distinguish subspecies in $S$. nodiflorum. Individuals from cluster I conformed to Jacquin's illustration of the type specimen of $S$. nodiflorum, No. 326 in Icones Plantarum Rariorum/Editae N. J. Jacquin and also with $S$. nodiflorum subsp. nodiflorum sensu Henderson's (1974) plate 1. A number of individuals agreed in all respects with Solanum nodiflorum Jacq. subsp. nutans (type specimen Henderson 518 ), illustrated by plate 2 in Henderson (1974).

Cluster II contained solely accessions from the USA, which were also used by Dehmer (2001), and Dehmer and Hammer (2004). This cluster was $100 \%$ supported with NJ Jackknife value (Fig. 1). Individuals in this cluster compared with the type specimen of $S$. americanum at BM (Miller s.n.), illustrated by plate 3 in Henderson (1974). According to Henderson 
Table 2. Morphological comparison of $S$. nodiflorum, Brazilian Solanum sp. and S. americanum sensu stricto

\begin{tabular}{|c|c|c|c|}
\hline Characteristics & S. nodiflorum & Solanum sp. (Brazil) & S. americanum \\
\hline Shape of calyx lobes & Lanceolate & Obovate & Ovate lanceolate \\
\hline $\begin{array}{l}\text { Calyx lobe fusion from } \\
\text { the base }\end{array}$ & Lobes fused at the base & $\begin{array}{l}\text { Often } 2 \text { or } 3 \text { lobes } \\
\text { fused clearly above } \\
\text { the base }\end{array}$ & Lobes fused at the base \\
\hline Petal length (mm) & (4) $4.5-5(6)$ & $4-6$ & (7) $7.5-8(9)$ \\
\hline Petal width (mm) & (1.5) $1.9-2$ & (1.5) 2 & $2.5-3$ \\
\hline $\begin{array}{l}\text { Extent of corolla fusion } \\
\text { from the base }(\mathrm{mm})\end{array}$ & (0.5) $1-1.5$ & $0-0.5$ & Up to 2 \\
\hline Style length (mm) & (1.5) 2-2.5 (3) & (2) 3 & $4.3-5$ \\
\hline $\begin{array}{l}\text { Style exsertion } \\
\text { beyond anthers }\end{array}$ & $\begin{array}{l}\text { Equal or below the anthers, } \\
\text { if exserted only up } \\
\text { to } 0.5 \mathrm{~mm}\end{array}$ & $\begin{array}{l}\text { Rarely exserted, } \\
\text { if exserted } 0.5-1.5 \mathrm{~mm} \text {. }\end{array}$ & $\begin{array}{l}\text { Clearly exserted up } \\
\text { to } 2.5-3 \mathrm{~mm}\end{array}$ \\
\hline $\begin{array}{l}\text { Fruiting pedicel } \\
\text { orientation }\end{array}$ & Deflexed or erect & Erect and spreading & Erect and spreading \\
\hline Inflorescence type & $\begin{array}{l}\text { Umbellate cyme } \\
\text { or nearly so }\end{array}$ & Umbellate cyme & Extended umbellate cyme \\
\hline Fruit colour & Shiny black & Shiny black & Dull black \\
\hline
\end{tabular}

Note: Figures in parentheses refer to infrequent values below or above the regular range or value that was recorded

(1974) and Heiser et al. (1979) this is the taxon that accurately fits the protologue of S. americanum Mill.

Cluster III (100\% Jackknife support in the NJ tree) was exclusively composed of the Brazilian Solanum sp., for which no comparable type specimen was found.

Phylogenetic analyses. AFLP data generated by the two primer combinations gave similar MP trees in all heuristic searches performed (results not shown). Five clades representing the species recognized above (Fig. 1) where produced. Each clade was supported by MP consensus and Jackknife values higher than $90 \%$ except clade I representing $S$. nodiflorum that had a NJ Jackknife support of only $73 \%$. Sub-clades within $S$. nodiflorum, corresponding in part to the subclusters within cluster I in Fig. 1, were supported with consensus value of $97-100 \%$ but they were not supported with Jackknife values. At the species level, the MP tree topology was identical to the topology observed in the NJ tree.

\section{Discussion}

Species delimitation. The difficulty of distinguishing genetically controlled characteristics from phenotypic plasticity has long been known to impede species level taxonomy in section Solanum (Edmonds and Chweya 1997). Confusion has also emerged from having to use mostly herbarium material that often lacks the necessary diagnostic characteristics to make an objective judgement (Heiser et al. 1979). The present study shows that although material received or identified as S. americanum shows a general morphological resemblance, this taxon should be split into three genetically different species, namely (1) $S$. nodiflorum (cluster I) that is a widely distributed species, (2) $S$. americanum sensu stricto represented by central American material in cluster II, and (3) a different species represented by the Brazilian accessions grouping in cluster III. This conclusion is not only supported by the phenetic results as depicted in Fig. 1, but each of the three species is an 


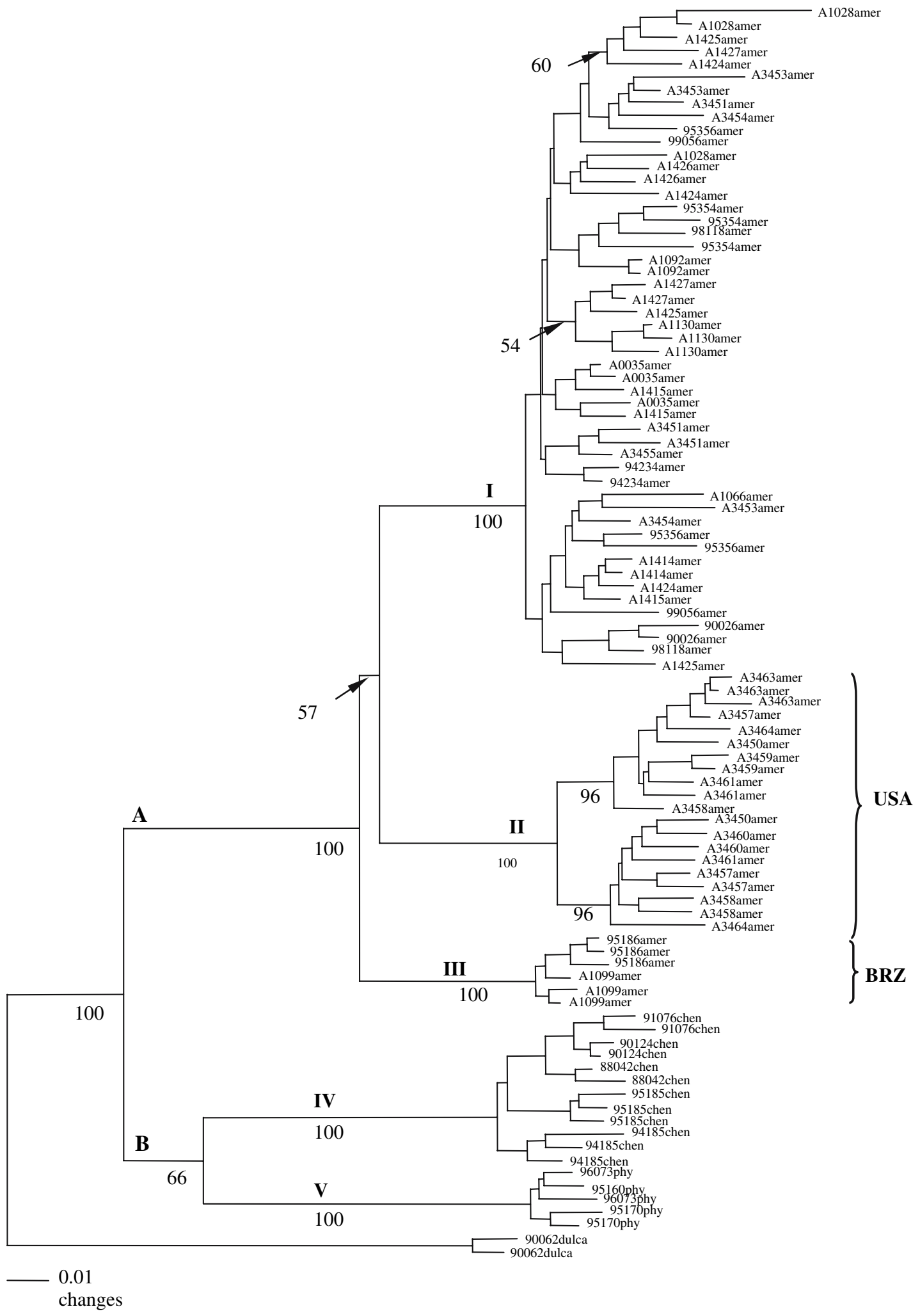

Fig. 1. NJ phenetic phylogram based on 435 polymorphic AFLP markers generated by the EcoRI $+\mathrm{AAC} /$ $M s e I+\mathrm{CAC}$ and $E c o \mathrm{RI}+\mathrm{ACC} / \mathrm{Mse} \mathrm{I}+\mathrm{CAT}$ primer combinations from 96 OTUs. Numbers below branches are NJ Jackknife support values 
independent lineage supported with consensus support values and Jackknife values in the MP tree (not shown).

Concerning the species status of $S$. nodiflorum and $S$. americanum sensu stricto therefore, this study does not support Edmonds (1971) and Edmonds (1972) combination of these taxa but rather agrees with previous numerical taxonomic studies which concluded that the two taxa were different species (Soria and Heiser 1961, Heiser et al. 1965, Heiser et al. 1979). Dehmer (2001) and Dehmer and Hammer (2004) showed that the Cuban and the USA accessions (the same ones as shown in Fig. 1) had a considerable genetic distance. Still, these authors placed the two groups under the same species: $S$. americanum and attributed the differences to geographical provenance. Our results disagree with this conclusion, indicating that these two groups fall into two different species, one of which (including the Cuban accessions) being a world wide species. The accessions that constitute $S$. nodiflorum occur in cluster I regardless of their geographical origin. Equally, our results do not support the placement of Ugandan material with Brazilian accession 95186amer under S. americanum as was done by Olet (2004).

The split between $S$. nodiflorum and $S$. americanum sensu stricto is also supported by previous studies on crossing behavior, often used to discriminate different biological species. In these studies it was found that the hybrids resulting from crossing the two species were abnormal, weak, with malformed abortive flowers and difficult to keep alive (Baylis 1958, Gray 1968, Henderson 1974, Heiser et al. 1979). We have also observed that $S$. nodiflorum starts to flower much earlier than $S$. americanum and that the former set fruits without any problem in the greenhouse, but not the latter.

Although these species show general morphological resemblance, it was observed during the present study that they could still be separated based on a combination of inflorescence and flower characteristics, especially the style exsertion (Table 2 and Fig. 2). The comparison of floral size between $S$. americanum sensu stricto on one end, and $S$. nodiflorum and the Brazilian Solanum sp. on the other, seems to indicate that $S$. americanum sensu stricto is superficially an enlarged version of the latter species. A similar pattern has been observed between $S$. sarrachoides Sendtn. and $S$. tweedianum Hook. where the latter is superficially an enlarged version of the former (Edmonds 1986). In both cases, individuals of these species have other characteristics in common such as pedicel posture, berry colour and shape, pubescence type, leaf shape, and other vegetative characteristics.

On the other hand, characteristics that have been used in some studies to differentiate $S$. americanum from $S$. nodiflorum, e.g. presence and absences of stone cells (Morton 1976, Heiser et al. 1979) or angle of pedicel inclination used by Morton (1976), showed no pattern in the present study when plotted on Fig. 1. Accessions with one or both of these characteristics were found in both $S$. nodiflorum, in $S$. americanum sensu stricto and the Brazilian Solanum sp. accessions. In Australian materials Henderson (1974), found stone cells in $S$. nodiflorum subsp. nutans but not in subsp. nodiflorum. Similarly, Olet (2004) recorded stone cells in one of the two forms of $S$. nodiflorum (there called $S$. americanum) in Uganda. In $S$. nodiflorum stone cells have hardly been a useful characteristic except for materials from North America (Heiser et al. 1979). Unpredictability of stone cells has also been demonstrated by Edmonds (1986) in $S$. sarrachoides and $S$. physalifolium Rusby. var. nitidibaccatum (Bitter) Edmonds.

It seems likely that this group of species has its origin in South America, the centre of genetic diversity of section Solanum species according to Edmonds and Chweya (1997). From here they spread to the USA probably through long distance dispersal of the seeds. The resulting widened range may have resulted into founder populations in the USA which through rapid speciation resulted into 

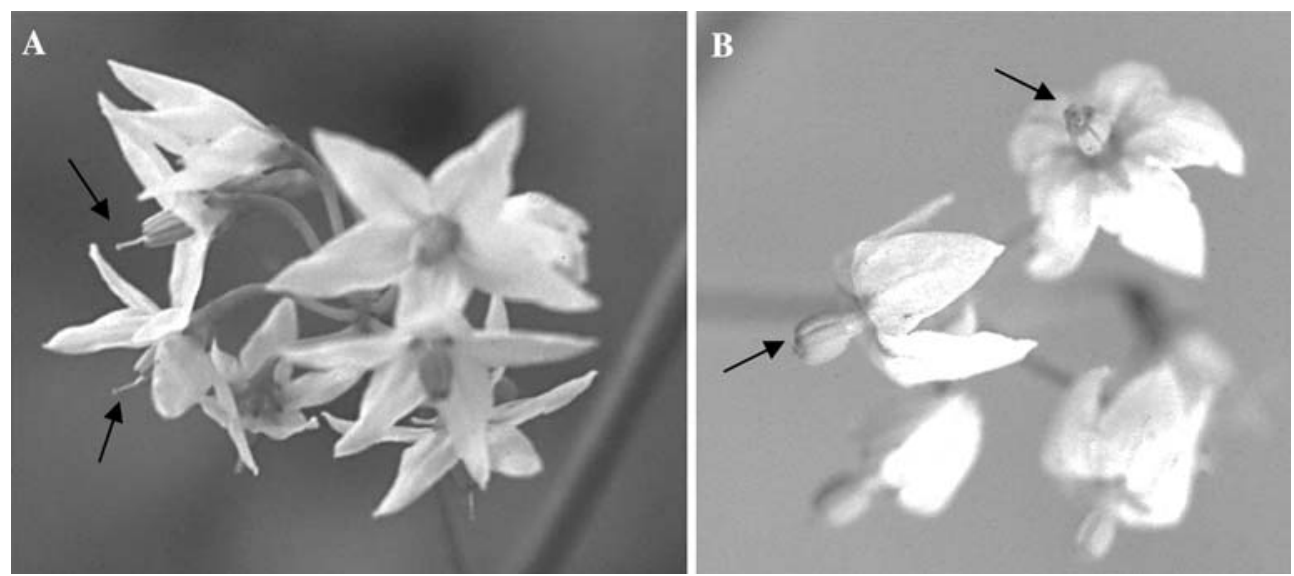

Fig. 2. Floral characteristics of S. americanum Mill. (A) and S. nodiflorum Jacq. (B). Arrows indicate the presence (A) and absence (B) of exserted styles

S. americanum sensu stricto, with large genetic differences - as shown by the NJ distances in Fig. 1 - not accompanied by large morphological differences. The wider distribution of $S$. nodiflorum can be explained based on the results of crossing studies by Soria and Heiser (1961) and Henderson (1974) that suggest that $S$. nodiflorum is an autogamous species, a mode of reproduction associated with colonisation ability, local adaptation and reproductive economy (Jain 1976). The fact that the three species still show general morphological resemblance suggests that the split is probably recent or that the new habitats the new taxa have evolved in did not impose selection pressure enough to bring about large physiological and morphological differences.

Infraspecific taxa. Earlier authors (Edmonds 1971, 1972; D’Arcy 1974b) recognized varieties within S. americanum sensu lato, but none of these are evident in our study. Actually, D'Arcy's S. americanum var. baylisii is, according to Edmonds and Chweya (1997), synonymous to $S$. chenopodioides, a different diploid species that constitutes cluster IV in the present study. Henderson (1974) recognized two subspecies in $S$. nodiflorum i.e. subsp. nutans and subsp. nodiflorum, but these cannot be recognized in the present results. The accessions that correspond to Henderson's subspecies nodiflorum are scattered in Fig. 1, and the subspecies is paraphyletic in the MP tree (not shown). Therefore, although there could be infraspecific structure within $S$. nodiflorum, based on the present study those subgroups cannot confidently be equated with Henderson's subspecies. Olet (2004) divided Ugandan materials into two morphological forms; $\mathrm{A}$ and $\mathrm{B}$ that were similar to $S$. nodiflorum subsp. nutans and S. nodiflorum subsp. nodiflorum, respectively, but her division was also not supported with AFLP data.

Nomenclatural considerations. Nomenclature changes, including the synonymy related to S. americanum, $S$. nodiflorum and the Brazilian Solanum sp. are beyond the scope of this study. However, the present study does have nomenclature implications and it recommends the use of the name $S$. americanum sensu stricto as used earlier (Soria and Heiser 1961, Heiser et al. 1965, Gray 1968, Henderson 1974, Heiser et al. 1979). This proposition is in conflict with Schilling (1981) who proposed to use the name $S$. ptycanthum Dunal in place of $S$. americanum. Actually, the latter name is also used for another diploid species commonly known as "eastern black nightshade", e.g. Bassett and Munro (1995), which is different from $S$. nodiflorum and $S$. americanum.

It is not possible to draw any conclusion about the nomenclature of the Brazilian Solanum sp. It is, however, known that Bitter 
(1912) described two taxa in Brazil that were close relatives of $S$. nodiflorum, namely $S$. tenellum and $S$. sciaphilum. While revising section Solanum in South America, Gray (1968) synonymised the two species under $S$. nodiflorum. Although no comparable type specimen was seen, it is possible that the Brazilian Solanum sp. in our study corresponds to one of these taxa, most likely $S$. tenellum which according to Bitter (1912) had the smallest flower in the whole genus.

On the other hand, our study has revealed the misapplication of some names. For example $S$. nigrum L., a name referring to a hexaploid species, is still being used for diploid S. nodiflorum in Mauritius, Mexico and India (Table 1). In Zimbabwe the name S. retroflex$u m$ (a tetraploid species) is also used for $S$. nodiflorum. We assigned accessions received as $S$. photeinocarpum Nakam. \& Odash. from China (Table 1) to S. nodiflorum. Both Gray (1968) and Henderson (1974) considered the former to be a synonym of the latter. Accession 95160phy was received as $S$. nitidibaccatum but it proved to be $S$. physalifolium. Edmonds (1986) reduced $S$. nitidibaccatum Bitt. to a synonym of $S$. physalifolium. Accession 95185chen received as S. ottonis Hylander /S. gracilius Hert. was certainly $S$. chenopodioides. Edmonds and Chweya (1997) considered both these names to be synonyms of $S$. chenopodioides. Solanum nodiflorum accession 94234amer from Hawaii was received as Nothocestrum latifolium. This is probably a labelling mistake, as this material certainly does not belong to this different genus.

At this point the following conclusions can be drawn: Cluster I represents a taxon that is distributed worldwide and should be known as $S$. nodiflorum. This is a tropical/subtropical taxon extending from the eastern coast of Africa, spreading over the Indian subcontinent and China to Australia and New Zealand. From the west coast of Africa $S$. nodiflorum extends westward into South America, the Caribbean Islands and Hawaii. In America this taxon extends from Georgia in the Southeast to California in the Southwest
(Schilling 1981). Solanum americanum sensu stricto from the USA is clearly different from $S$. nodiflorum. There is no support in the AFLP data for the existence of subspecies within S. nodiflorum.

The authors acknowledge funding for this project from Nuffic through MHO-ENVIRONS program and the Faculty of Science Radboud University Nijmegen. They also wish to thank Mr. Jelle Eygensteyn for his assistance during AFLP analysis on the Beckman.

\section{References}

Bassett I. J., Munro D. B. (1995) The biology of Canadian weeds. Solanum ptycanthum Dun., $S$. nigrum L. and $S$. sarrachoides Sendtn. 65: 401-414.

Baylis G. T. S. (1958) A cytogenetic study of New Zealand forms of Solanum nigrum L., Solanum nodiflorum Jacq. and $S$. gracile Otto. Trans. Proc. Roy. Soc. NZ

Becker J., Kuiper M., Vos P., Salamini F., Heun M. (1995) Combined mapping of AFLP and RFLP markers in barley. Molec. Gen. Genet. 249: 6573.

Bitter G. (1912) Solana nova vel minus cognita. III. Repert. Spec. Nov. Regni Veg. 11: 202-237.

Bosser J., Cadet T., Gueho J., Marais W. (2000) Flore des Mascareignes: La Réunion, Maurice and Rodrigues. The Royal Botanical Gardens, Kew.

Coulibaly S., Pasquet R. S., Papa R., Gepts P. (2002) AFLP analysis of the phenetic organisation and genetic diversity of Vigna unguiculata (L.) Walp. reveals extensive gene flow between wild and domesticated types. Theor. Appl. Genet. 104: 358-366.

D'Arcy W. G. (1974a) Flora of Panama. Ann. Missouri Bot. Gard. 60: 573-780.

D'Arcy W. G. (1974b) Solanum and its close relatives in Florida. Ann. Missouri Bot. Gard. 61: 819-867.

D’Arcy W. G., Rakotozafy A. (1994) Famille 176. Solanaceae. In: Morat P. (ed.) Flore de Madagascar et des Comores. Museum Nationale d'Histoire Naturelle, Paris.

Dehmer K. J. (2001) Conclusions on the taxonomy of the Solanum nigrum complex by molecular analyses of IPK germplasm accessions. In: van 
den Berg R. G., Barendse G. W. M., van der Weerden G. M., Mariani C. (eds.) Solanaceae $\mathrm{V}$ : Advances in taxonomy and utilization. University Press, Nijmegen, pp. 85-96.

Dehmer K. J., Hammer K. (2004) Taxonomic status and geographic provenance of germplasm accessions in Solanum nigrum L. complex: AFLP data. Gen. Res. Crop Evol. 51: 551-558.

Edmonds J. M. (1971) Solanum L. In: Taxonomic and nomenclatural notes on Jamaican gamopetalous plants (W. T. Stearn). J. Arnold Arbor. 52: 634-635.

Edmonds J. M. (1972) A synopsis of the taxonomy of Solanum L. section Solanum (Maurella) in South America. Kew Bull. 27: 95-114.

Edmonds J. M. (1986) Biosystematics of Solanum sarrachoides Sendtn. and S. physalifolium Rusby (S. nitidibaccatum Bitter). Bot. J. Linn. Soc. 92: $1-38$.

Edmonds J. M., Chweya J. A. (1997) Black nightshades Solanum nigrum L. and related species. Institute of Plant Genetics and Crop Plant Research, Gatersleben/International Plant Genetic Resources Institute, Rome, pp. 5-113.

Gentry J. L., Standley P. C. (1974) Solanaceae. In: Flora of Guatamala. Fieldiana Bot. 24(10): $1-151$.

Gray J. M. (1968) The taxonomy of the Morella section of the genus Solanum L. within South America. Ph.D. thesis, Birmingham University, Birmingham.

Heiser C. B., Soria J., Burton D. L. (1965) A numerical taxonomic study of Solanum species and hybrids. Amer. Naturalist 99: 471-488.

Heiser C. B., Burton D. L., Schilling E. E. (1979) Biosystematic and taxometric studies of the Solanum nigrum complex in eastern North America. In: Hawkes J. G., Lester R. N., Skelding A. D. (eds.) The biology and taxonomy of the Solanaceae. Academic Press, London, pp. 513-527.

Henderson R. J. F. (1974) Solanum nigrum L. (Solanaceae) and related species in Australia. Contrib. Queensl. Herb. 16: 1-78.

Howard R. A. (1989) Flora of Lesser Antilles, Leeward and Windward Islands. Solanaceae, Vol. 6. Arnold Arboretum, Harvard University, Jamaica Plain, MA.

Jacoby A., Labuschagne M. T., Viljoen C. D. (2003) Genetic relationships between Southern African Solanum retroflexum Dun. and other related species measured by morphological and DNA markers. Euphytica 132: 109-113.

Jain S. K. (1976) The evolution of inbreeding in plants. Ann. Rev. Ecol. Syst. 7: 469-495.

Kardolus J. P., van Eck H. J., van den Berg R. G. (1998) The potential of AFLPs in biosystematics: a first application in Solanum taxonomy (Solanaceae). Pl. Syst. Evol. 210: 87-103.

Knapp S. (2001) Is morphology dead in the Solanum taxonomy? In: van den Berg R. G., Barendse G. W. M., van der Weerden G. M., Mariani C. (eds.) Solanaceae V: Advances in taxonomy and utilization. University Press, Nijmegen, pp. 23-38.

Mace E. S., Lester R. N., Gebhardt C. G. (1999a) AFLP analysis of genetic relationships among the cultivated eggplant, Solanum melongena L., and wild relatives (Solanaceae). Theor. Appl. Genet. 99: 626-633.

Mace E. S., Lester, R. N. Gebhardt, C. G. (1999b) AFLP analysis of genetic relationships in tribe Daturae (Solanaceae). Theor. Appl. Genet. 99: 634-633.

Manoko M. L., van der Weerden G. M. (2004) Solanum americanum. In: Grubben G. J. H., Denton O. A. (eds.) Plant resources of Tropical Africa 2. Vegetables. PROTA Foundation Wageningen/CTA Wageningen, Backhuys Publishers, Leiden, pp. 477-480.

Morton C. V. (1976) Revision of the Argentine species of Solanum. Academia Nacional de Ciencias, Cordoba, Republica Argentina, pp. 7-260.

Olet E. A. (2004) Taxonomy of Solanum L. section Solanum in Uganda. Ph.D. thesis, Agricultural University of Norway.

Rademaker J. L. W., Hoste B., Louws F. J., Kersters K., Swings J., Vauterin L., Vauterin P., de Bruijn, F. J. (2000) Comparison of AFLP and rep-PCR genomic fingerprinting with DNADNA homology studies: Xanthomonas as a model system. Int. J. Syst. Evol. Microbiol. 50: 665-677.

Schilling E. E. (1981) Systematics of Solanum sect. Solanum (Solanaceae) in North America. Syst. Bot. 6: 172-185.

Schippers R. R. (2000) African indigenous vegetables. An overview of the cultivated species. Natural Resources Institute/ACP-EU Technical Centre of Agricultural and Rural Cooperation, Chatham, pp. 147-176. 
Soria J., Heiser C. B. (1961) A statistical study of relationships of certain Solanum nigrum complex. Econ. Bot. 15: 245-255.

Swofford D. (2001) PAUP* Phylogenetic Analysis Using parsimony (*and other methods) version 4b10. Sinauer Associates, Sunderland.

Symon D. E. (1981) A revision of the genus Solanum in Australia. J. Adelaide Bot. Gard. 4: $1-367$.

Symon D. E. (1985) The Solanaceae of New Guinea. J. Adelaide Bot. Gard. 8: 1-171.

Templeton A. R. (1980) Modes of speciation and inferences based on genetic distances. Evolution 34: 719-729.

Vos P., Hogers R., Bleeker M., Reijans M., van de Lee T., Hornes M., Frijters A., Pot J., Peleman J., Kuiper M., Zabeau M. (1995) AFLP: a new technique for DNA fingerprinting. Nucl. Acids Res. 23: 4407-4414.
Waugh R., Bonar N., Baird E., Thomas B., Graner A., Hayes P., Powell W. (1997) Homology of AFLP products in three mapping populations of barley. Molec. Gen. Genet. 255: 311-321.

Wiggins I. L. (1980) Flora of Baja California. Stanford University Press, Stanford.

Addresses of the authors: Mkabwa L. K. Manoko, Richard M. C. Feron, and Celestina Mariani, Department of Experimental Botany, Radboud University Nijmegen, Toernooiveld 1, 6525 ED Nijmegen, The Netherlands. Ronald G. van den Berg (e-mail: Ronald.vandenBerg@wur.nl), Biosystematics group, Wageningen University, Gen. Foulkesweg 37, 6703 BL Wageningen, The Netherlands. Gerard M. van der Weerden, Botanical and Experimental Garden, Radboud University Nijmegen, Toernooiveld 11, 6525 ED Nijmegen, The Netherlands. 